\title{
PERAN PENDIDIKAN PERDAMAIAN KAITANNYA DENGAN PAK DALAM MENGHADAPI MASYARAKAT EKONOMI ASEAN (MEA)
}

\author{
Djoys Anneke Rantung \\ Universitas Kristen Indonesia \\ Program Studi Magister Pendidikan Agama Kristen \\ djoys.anneke@gmail.com
}

\begin{abstract}
Abstrak
Masyarakat Ekonomi Asean sementara berlangsung di negara-negara Asean dengan berbagai bentuk kerjasama di berbagai bidang yang berfokus pada bidang ekonomi. Hal ini menjadi peluang sekaligus tantangan bagi setiap bangsa yang terlibat di dalamnya dan terutama bagi bangsa Indonesia. Peluang dan tantangan harus segera disikapi dan dihadapi. Jika tidak, akibatnya bisa merugikan dan bukan menguntungkan. Peningkatan kualitas pendidikan yang baik haruslah dimiliki oleh anak bangsa dalam menghadapi MEA sebagai kunci kesuksesan. Berbagai konflik dapat saja terjadi sebagai dampak dari Masyarakat Ekonomi Asean. Bilamana konflik tidak segera diatasi maka dampaknya akan menjadi semakin buruk dan konflik tersebut dapat berpeluang pada tindakan kekerasan. Pendidikan perdamaian haruslah menjadi agenda utama dalam kehidupan setiap orang, terutama mencegah dan mengatasi berbagai konflik sebagai dampak negatif dari MEA. Pendidikan perdamaian kaitannya dengan PAK, mengajarkan setiap orang untuk hidup dalam rasa aman, nyaman, bebas dari berbagai masalah atau dapat menangani berbagai konflik. Pentingnya pendidikan perdamaian terutama dalam menghadapi MEA ini, supaya semua pihak dapat menjalin hubungan dengan baik.
\end{abstract}

Kata Kunci: Pendidikan, Pendidikan Perdamaian, Pendidikan Agama Kristen, Masyarakat Ekonomi Asean.

\section{Pendahuluan}

Proses globalisasi sudah dan sedang terjadi di Indonesia, di mana Indonesia pun terlibat dalam proses tersebut termasuk persaingan yang semakin meluas dalam berbagai bentuk berupa arus barang dan jasa tenaga kerja dan arus modal. Masyarakat Ekonomi Asean (MEA) merupakan salah satu peluang, sekaligus tantangan bagi Indonesia dalam menghadapi abad ekonomi Asia ini. Melalui MEA, akan terjadi integrasi sektor ekonomi. Persaingan tenaga kerja di dalam MEA akan sangat ketat. Bagaimana pun di dalam dunia pasar bebas MEA, Indonesia akan dibanjiri oleh tenaga kerja dan pelaku usaha dari negara asing di kawasan ASEAN. Kesiapan Indonesia dalam menghadapi proses globalisasi ini sangat penting, terutama Sumber Daya Manusianya. Tanpa SDM yang terampil, mumpuni dan profesional yang dimiliki oleh masyarakat Indonesia, maka dapat dipastikan Indonesia hanya akan menciptakan para tenaga kerja kasar, seperti buruh dan pembantu rumah tangga. 
Konsep utama dari MEA adalah menciptakan ASEAN sebagai sebuah pasar tunggal dan kesatuan basis produksi di mana terjadi free flow atas barang, jasa, faktor produksi, investasi dan modal serta penghapusan tarif bagi perdagangan antar negara ASEAN yang kemudian diharapkan dapat mengurangi kemiskinan dan kesenjangan ekonomi di antara negaranegara anggotanya melalui sejumlah kerjasama yang saling menguntungkan. Dipilihnya Indonesia sebagai pusat perdagangan bebas MEA, mendorong pemerintah Indonesia untuk melakukan persiapan, mulai dari persiapan infrastruktur sampai kepada persiapan dalam menciptakan Sumber Daya Manusia (SDM) masyarakat Indonesia yang terampil, mumpuni dan profesional.

Untuk menciptakan SDM yang terampil dan profesional, tidak terlepas dari pendidikan yang berkualitas. Tanpa pendidikan yang berkualitas, harapan untuk menciptakan SDM yang terampil dan profesional hanya akan menjadi sebuah harapan. Pendidikan merupakan peran penting dalam membangun sumber daya manusia yang kompetitif dan mampu bersaing dengan negara lain. Oleh karena itu, untuk menyambut MEA 2016, pendidikan harus mampu mempersiapkan sumber daya manusia (SDM) yang terampil, peka dan kritis dalam menghadapi tantangan maupun perubahan- perubahan yang akan terjadi di dunia pendidikan mendatang. Tantangan MEA dalam dunia pendidikan yang akan dihadapi, antara lain: menjamurnya lembaga pendidikan asing, standar dan orientasi pendidikan yang makin pro pasar, serta pasar tenaga kerja yang dibanjiri tenaga kerja asing.

Indonesia perlu bersikap terbuka pada pendidikan perdamaian dalam menghadapi MEA. Anak-anak yang menjadi generasi penerus bangsa merupakan modal bangsa yang harus betul-betul digarap kecerdasan intelektual, spiritual, dan emosionalnya. Mengingat di pundak merekalah nasib bangsanya ditentukan. Di berbagai media massa sering kita saksikan fenomena pelajar merusak kampus, perkelahian antar pelajar, berita tentang kenakalankenakalan remaja, permusuhan, dan berbagai konflik lain. Untuk itu, pendidikan perdamaian di sekolah-sekolah saat ini haruslah bertujuan untuk mengatasi ketidakseimbangan tersebut. Tujuannya tidak lain adalah untuk membantu mewujudkan situasi kehidupan yang rukun, aman, tenang, dan tanpa konflik. Memberikan sebuah wacana kehidupan yang lain bahwa masyarakat kita mampu untuk hidup harmonis dengan sesama manusia, dan dengan seisi bumi ini. 
Banyak sikap yang baik untuk dikembangkan dan untuk membangun sebuah masyarakat dan dunia yang baik. Sikap tersebut antara lain: menghormati diri sendiri, toleransi, empati, keadilan, kejujuran, tidak saling mencurigai, persahabatan, kerjasama, saling pengertian, dan keadilan/pemerataan. Damai adalah suatu suasana di mana tidak terdapat permusuhan dan hal ini menunjuk pada hubungan yang serasi antara dua pihak atau lebih. Pada akhirnya setiap orang harus memberikan sumbangannya untuk perdamaian dunia. Masalah yang kelihatannya dominan di masyarakat kita adalah terjadinya konflik yang berpangkal pada tidak adanya saling pengertian dan sifat mudah tersinggung. Kadang konflik seperti ini juga mengarah pada berbagai bentuk kekerasan. Di sini orang sepertinya tidak menghargai diri sendiri. Begitu mudah nyawa dijadikan taruhannya hanya karena tidak bisa mengendalikan emosi. Oleh karena itu, pendidikan perdamaian di sekolah-sekolah lebih difokuskan pada penanaman nilai-nilai di atas. Selain sikapsikap di atas, dalam pendidikan perdamaian juga harus mampu mengembangkan keterampilanketerampilan, seperti: mampu berkomunikasi, mendengarkan, memahami pandangan-pandangan yang berbeda, mampu bekerjasama, pemecahan masalah, berpikir kritis, pengambilan keputusan, pemecahan konflik, dan tanggung jawab sosial.

Menyiapkan sumber daya manusia yang kompetitif memang bukan pekerjaan mudah yang dapat dilakukan secara instan. Akan tetapi, apabila pendidikan di Indonesia mampu membekali siswa dengan pengetahuan serta keterampilan yang memadai, maka lulusan pendidikan Indonesia akan memiliki rasa percaya diri serta motivasi yang tinggi untuk mengembangkan diri secara optimal sehingga mampu bersaing secara global.

Bagi Indonesia, keberadaan MEA menjadi babak awal untuk mengembangkan berbagai kualitas perekonomian di kawasan Asia Tenggara dalam perkembangan pasar bebas di akhir 2016. MEA menjadi dua sisi mata uang bagi Indonesia: satu sisi menjadi kesempatan yang baik untuk menunjukkan kualitas dan kuantitas produk dan sumber daya manusia (SDM) Indonesia kepada negara-negara lain dengan terbuka, tetapi pada sisi yang lain dapat menjadi bumerang untuk Indonesia apabila Indonesia tidak dapat memanfaatkannya dengan baik.

Indonesia harus melihat MEA sebagai peluang yang terbuka untuk memperbaiki kualitas SDM yang ada dengan meningkatkan daya saing, menyediakan pendidikan dan kesehatan yang memadai, dan memberikan edukasi 
terhadap pentingnya MEA 2016. Hal yang lebih penting adalah mengarusutamakan pendidikan perdamaian dalam semua aspek kehidupan baik sebagai tindakan pencegahan dan penanganan konflik. Karena, masalah-masalah dapat terjadi sebagai konsekuensi dari MEA. Konflik dan kekerasan dapat disebabkan faktor ketidakadilan ekonomi, kemiskinan, marjinalisasi, masalah lingkungan, pelanggaran hak asasi manusia, dan sebagainya.

Pendidikan perdamaian dapat mengubah cara pandang dan mengurangi konflik dengan cara mempromosikan kesejahteraan, perdamaian melalui non kekerasan dan menggagas metode penyelesaian konflik. Diharapkan peran pendidikan perdamaian dapat juga mengatasi segala konsekuensi yang terjadi dalam menghadapi MEA.

\section{Tinjauan Teoritis}

\section{Masyarakat Ekonomi Asean}

Masyarakat Ekonomi ASEAN (MEA) 2015 (ASEAN Economic Community (AEC)) adalah sebuah integrasi ekonomi ASEAN dalam menghadapi perdagangan bebas antar sesama negara-negara ASEAN. MEA merupakan sebuah sistem pasar bebas antara sesama negara anggota ASEAN yang menghilangkan pajak atau bea cukai, serta kebebasan sebuah negara untuk memasukkan barangnya ke negara lainnya. MEA atau AEC merupakan salah satu bentuk kerjasama ASEAN di bidang Ekonomi. Masyarakat Ekonomi ASEAN (MEA) sendiri telah dibuka pada Desember 2015 lalu dengan tujuan untuk memujudkan wawasan ASEAN pada tahun 2020.

Masyarakat Ekonomi ASEAN merupakan pasar tunggal yang memiliki pola pengintegrasian ekonomi ASEAN dengan cara membentuk sistem perdagangan bebas di antara negara-negara anggora ASEAN. Pembentukan dan pendirian MEA telah disepakati oleh negara-negara anggota ASEAN, melalui pemerintah masing-masing negara. Dengan adanya MEA akan memungkinkan satu negara menjual barang dan jasa dengan mudah ke negaranegara lain di seluruh Asia Tenggara, sehingga kompetisi akan semakin ketat. Itu berarti sejak diberlakukannya MEA pada akhir tahun 2015, perdagangan bebas yang mencakup barang dan jasa antar sesama negara anggota ASEAN tidak ada batasnya lagi. Sebuah pasar tunggal untuk barang dan jasa akan memfasilitasi pengembangan jaringan produksi di wilayah ASEAN dan meningkatkan kapasitas ASEAN sebagai pusat produksi global dan sebagai bagian dari rantai pasokan dunia. Tarif akan dihapuskan dan 
hambatan non-tarif secara bertahap juga akan dihapus. Perdagangan dan sistem kepabeanan yang terstandarisasi, sederhana dan harmonis diharapkan dapat mengurangi biaya transaksi. Akan ada pergerakan bebas para profesional. Investor ASEAN akan bebas untuk berinvestasi di berbagai sektor, dan sektor jasa akan dibuka.

Secara umum MEA bertujuan untuk membentuk komunitas ekonomi tingkat regional antara sesama negara anggota ASEAN sebagai suatu integrasi ekonomi kawasan ASEAN yang stabil, makmur dan memiliki tingkat daya saing yang tinggi. Selain itu juga untuk mempercepat pertumbuhan ekonomi, kemajuan sosial dan pengembangan kebudayaan khususnya di wilayah ASEAN. Tujuan utama MEA adalah ingin menghilangkan secara signifikan hambatan-hambatan kegiatan ekonomi lintas kawasan tersebut, yang diimplementasikan melalui 4 pilar utama, yaitu: ASEAN sebagai pasar tunggal dan basis produksi internasional (single market and production base) dengan elemen aliran bebas barang, jasa, investasi, tenaga kerja terdidik dan aliran modal yang lebih bebas, ASEAN sebagai kawasan dengan daya saing ekonomi yang tinggi (competitive economic region), dengan elemen peraturan kompetisi, perlindungan konsumen, hak atas kekayaan intelektual, pengembangan infrastruktur, perpajakan, dan e-commerce, ASEAN sebagai kawasan dengan pengembangan ekonomi yang merata (equitable economic development) dengan elemen pengembangan usaha kecil dan menengah, dan prakarsa integrasi ASEAN untuk negara-negara CMLV (Cambodia, Myanmar, Laos, dan Vietnam), dan ASEAN sebagai kawasan yang terintegrasi secara penuh dengan perekonomian global (integration into the global economy) dengan elemen pendekatan yang koheren dalam hubungan ekonomi di luar kawasan, dan meningkatkan peran, serta dalam jejaring produksi global. MEA tidak hanya membuka arus perdagangan dalam bidang barang dan jasa, tetapi juga pasar tenaga kerja profesional, seperti: guru, dokter, perawat, pengacara dan lain-lain. Dalam hal ini, peraturan-peraturan yang sebelumnya dianggap mempersulit bahkan menghalangi perekrutan tenaga kerja asing akan dihapuskan. Hampir semua sektor akan berkontribusi dalam Masyarakat Ekonomi Asean dengan meminimalisasi bahkan meniadakan semua hambatan dalam kerjasama Masyarakat Ekonomi Asean.

Bentuk-bentuk kerjasama yang dilakukan dalam MEA adalah:

- Pengembangan sumber daya manusia dan peningkatan kapasitas. 
- Pengakuan pada kualifkasi profesional tenaga kerja.

- Konsultasi yang lebih dekat pada kebijakan makro keuangan dan ekonomi.

- Memiliki langkah-langkah dalam pembiayaan perdagangan.

- Meningkatkan infra struktur.

- Melakukan pengembangan pada transaksi elektronik melalui e-ASEAN.

- Memadukan semua industri yang ada di seluruh wilayah ASEAN untuk dapat mempromosikan sumber daerah.

- Meningkatkan peran sektor swasta untuk membangun MEA.

Adapun ciri-ciri MEA adalah:

- Kawasan ekonomi yang sangat kompetitif. MEA memerlukan kebijakan-kebijakan yang menciptakan iklim persaingan yang adil, adanya perlindungan berupa sistem jaringan dari agen-agen perlindungan konsumen, mencegah pelanggaran hak cipta, adanya jaringan transportasi yang efisien, aman, dan terintegrasi, menghilangkan sistem double taxation, meningkatkan perdagangan dengan media elektronik berbasis online.

- Memiliki wilayah pembangunan ekonomi yang merata dengan memprioritaskan pada Usaha Kecil Menengah (UKM). Kemampuan daya saing dan dinamisme UKM ditingkatkan dengan memfasilitasi akses terhadap informasi terkini, kondisi pasar, pengembangan sumber daya manusia, meningkatkan tekhnologi dan keuangan.

- Daerah-daerah akan terintegrasi secara penuh dalam ekonomi global. Sebuah sistem untuk meningkatkan koordinasi terhadap negara-negara anggota akan dibangun. Adanya peningkatan kemampuan industri dan produktivitas, sehingga terjadi juga peningkatan partisipasi pada skala regional dan memunculkan inisiatif untuk terintegrasi secara global.

- Basis produksi dan pasar tunggal. Negara-negara di kawasan Asia Tenggara akan dijadikan sebuah wilayah kesatuan pasar dan basis produksi, sehingga membuat arus barang, jasa, investasi dan skill labour menjadi tanpa hambatan dari satu negara ke negara lainnya.

\section{Dampak Masyarakat Ekonomi ASEAN Bagi Indonesia}

Keberadaan MEA memberikan dampak bagi negara-negara ASEAN, termasuk masyarakat Indonesia. Hal tersebut dapat terjadi sebagai efek dari arus bebas dan perjumpaan, serta interaksi berbagai pihak dari berbagai negara terhadap MEA tersebut. Dampak-dampak tersebut tersebut bisa berdampak bagi 
perdagangan, investasi dan ketenagakerjaan, tetapi juga dapat berdampak pada relasi/hubungan pribadi/individu dengan orang lain, kelompok bahkan negara yang baik dan harmonis atau bebas dari masalah atau konflik. Adapun dampak-dampaknya, sebagai berikut:

\section{a. Dampak Positif}

\section{- Pada Perdagangan}

Menurut Santoso, MEA akan menjadi kesempatan yang baik karena hambatan perdagangan akan cenderung berkurang bahkan menjadi tidak ada. Hal tersebut akan berdampak pada peningkatan eskpor yang pada akhirnya akan meningkatkan Gross Domestik Product (GDP) Indonesia. Kegiatan produksi dalam negeri meningkat secara kuantitas dan kualitas; mendorong pertumbuhan ekonomi negara, pemerataan pendapatan masyarakat, dan stabilitas ekonomi nasional; serta menambah devisa negara melalui bea masuk dan biaya lain atas ekspor dan impor. Dengan memulai impor, kebutuhan dalam negara dapat terpenuhi dan dapat memperluas lapangan kerja dan kesempatan masyarakat untuk bekerja.

\section{- Pada Investasi}

Kondisi ini dapat menciptakan iklim yang mendukung masuknya Foreign
Direct Investment (FDI) yang dapat menstimulus pertumbuhan ekonomi melalui perkembangan teknologi, penciptaan lapangan kerja, pengembangan sumber daya manusia (human capital) dan akses yang lebih mudah kepada pasar dunia. Indonesia dapat menstabilkan perekonomian negara menjadi lebih baik. Salah satu contohnya, adanya pasar bebas di mana barang Indonesia dapat memperluas jangkauan ekspor dan impor tanpa ada biaya dan penahanan barang terlalu lama di bea cukai. Para investor dapat memperluas ruang investasinya tanpa ada batasan ruang antar negara anggota ASEAN. Para pengusaha akan semakin kreatif karena persaingan yang ketat, para tenaga kerja akan semakin meningkatkan tingkat profesionalitas dan bakat yang dimilikinya. Para penanam modal dari Indonesia semakin jeli dalam memilih, dan banyak hal positif lainnya yang dapat dinikmati Indonesia dengan adanya Asean Economic Community pada tahun 2015.

\section{- Pada Sisi Ketenagakerjaan}

Terdapat kesempatan yang sangat besar bagi para pencari kerja karena dapat banyak tersedia lapangan kerja dengan berbagai kebutuhan akan keahlian yang beraneka ragam. Selain itu, akses untuk pergi keluar negeri dalam rangka mencari pekerjaan menjadi lebih mudah bahkan 
bisa jadi tanpa ada hambatan tertentu. MEA juga menjadi kesempatan yang bagus bagi para wirausahawan untuk mencari pekerja terbaik sesuai dengan kriteria yang diinginkan. Para tenaga kerja Indonesia juga dapat bekerja di negara anggota ASEAN dengan bebas dan sesuai dengan keterampilan yang dimilikinya. Tenaga terampil di Indonesia akan lebih banyak terserap di luar negri, tenaga terampil yang selama ini mempunyai sedikit peluang misalnya sektor kreatif dan UKM. Harga-harga kemungkinan menjadi lebih murah, karena ketersediaan barang lebih besar dan proses pengadaan berbiaya murah.

Dampak positif lainnya yaitu, kita bangsa Indonesia akan mampu menghadapi berbagai macam tantangan dalam menyambut datangnya era Masyarakat Ekonomi ASEAN. Apabila kita mempunyai daya saing yang kuat, persiapan yang matang, produk-produk dalam negeri akan menjadi tuan rumah di negeri sendiri dan kita mampu memanfaatkan kehadiran MEA untuk menikmati dampak positif bagi kepentingan bersama dan untuk kemakmuran rakyat Indonesia. Tenaga terampil di Indonesia akan lebih mudah terserap di luar negeri dan dengan adanya MEA suhu perekonomian di Indonesia akan semakin meningkat. Harga-harga kemungkinan akan lebih murah, impor dapat memenuhi kebutuhan masyarakat yang belum mampu secara lokal. Sektor wirausaha akan terbuka lebar, relasi bisnis dan pasar lebih terbuka seiring luasnya jangkauan pasar dan penyebaran produk. Jadi, ekspor dan impor tidaklah selalu dimainkan pemain besar (kartel). Selain itu, dampak posifnya adalah menambah devisa negara yang didapatkan dari ekspor barang ke luar negeri.

\section{b. Dampak Negatif}

\section{- Pada Sisi Kompetisi}

Kompetisi akan muncul dengan banyaknya barang impor yang akan mengalir dalam jumlah banyak ke Indonesia yang akan mengancam industri lokal dalam bersaing dengan produkproduk luar negri yang jauh lebih berkualitas. Hal ini pada akhirnya akan meningkatkan defisit neraca perdagangan bagi negara Indonesia sendiri.

\section{- Pada Sisi Ekploitasi}

Eksploitasi dengan skala besar terhadap ketersediaan sumber daya alam oleh perusahaan asing yang masuk ke Indonesia sebagai negara yang memiliki jumlah sumber daya alam melimpah dibandingkan negara-negara lainnya. Tidak tertutup kemungkinan juga eksploitasi yang dilakukan perusahaan asing dapat merusak ekosistem di Indonesia, sedangkan regulasi investasi 
yang ada di Indonesia belum cukup kuat untuk menjaga kondisi alam termasuk ketersediaan sumber daya alam yang terkandung.

\section{- Pada Ketenagakerjaan}

Dampak negatif pada sisi ketenagakerjaan dapat dilihat dari sisi pendidikan dan produktivitas Indonesia masih kalah bersaing dengan tenaga kerja yang berasal dari Malaysia, Singapura, dan Thailand, serta fondasi industri yang bagi Indonesia sendiri membuat Indonesia berada pada peringkat keempat di ASEAN. Menurut Media Indonesia, Kamis 27 Maret 2014, adanya pasar barang dan jasa secara bebas akan mengakibatkan mudahnya tenaga kerja asing masuk dan bekerja di Indonesia sehingga mengakibatkan persaingan tenaga kerja yang semakin ketat di bidang ketenagakerjaan.

Dampak negatif lainnya, yaitu sesuai dengan pilar MEA 2015, pembatasan tenaga kerja profesional akan dihapuskan. Hal tersebut memberikan kesempatan tenaga kerja asing untuk masuk dalam lapangan kerja di Indonesia. Dampaknya adalah kesempatan untuk mendapatkan pekerjaan di Indonesia semakin kecil. Selain itu, kemampuan berbahasa tenaga kerja Indonesia juga masih dianggap kurang, dan kesiapan tenaga kerja Indonesia hanya bergantung pada mental.

Dampak arus bebas investasi menimbulkan eksploitasi sumber daya yang ada di Indonesia oleh perusahaan asing. Apabila Indonesia tidak dapat menanganinya dengan baik, maka eksploitasi besar-besaran akan membuat Indonesia mengalami kerugian. Selain itu, Indonesia juga masih bergantung pada impor barang luar negeri. Indonesia kebanyakan hanya mengekspor barang mentah atau barang setengah jadi. Apabila kegiatan ekspor-impor tersebut tidak dapat dijalankan dengan baik maka Indonesia akan diserbu oleh barang impor. Perusahaan Indonesia juga melemah karena tidak sanggup bertahan dengan serbuan barang impor. Ketersediaan dan kualitas infrastruktur di Indonesia masih kurang. Jalur-jalur darat, air maupun udara untuk menghubungkan pulau-pulau di Indonesia dan negara lain belum memadai. Hal tersebut memberi dampak pada kelancaran arus ekspor dan impor di Indonesia.

\section{Cara Menghadapi Dampak MEA}

Kehadiran MEA adalah titik terang karena bisa mendatangkan kebaikan, yakni kesempatan dalam berbagai bidang usaha dan pekerjaan semakin terbuka, tetapi bersamaan dengan itu, persaingan pun 
tidak bisa dihindari. Munculnya sebuah persaingan tentu sudah dapat diprediksi akan menyebabkan banyak masalah terjadi. Kata persaingan sendiri di Indonesia sudah menunjukkan hal-hal yang berkonotasi negatif. Padahal persaingan belum tentu akan membawa hasil yang buruk untuk masyarakat Indonesia.

Menghadapi persaingan dengan masyarakat negara ASEAN lainnya akan menyebabkan semakin mudahnya masyarakat asing yang kompetitif dan berkualitas menduduki posisi-posisi lapangan pekerjaan di Indonesia. Hal ini tidak menutup kemungkinan bahwa mereka yang tidak mampu bersaing akan tergerus; banyak yang akan kehilangan pekerjaan dan menjadi pengangguran, dsb. Hal ini akan berdampak dengan terjadinya kesenjangan ekonomi; menciptakan komunitas yang merasa dirugikan dan diabaikan, miskin dan pra sejahtera. Kesenjangan ekonomi dan sosial dapat memicu munculnya konflik yang bisa berakibat pada kekerasan. Hilangnya lapangan pekerjaan dapat menimbulkan masalah sosial, yang sesungguhnya harus diperhatikan oleh semua pihak. Masalah sosial ini dapat menjadi pemicu konflik yang berdampak pada hubungan antar pribadi/sesama, kelompok, bangsa dan negara. Masalah lain adalah masalah ekonomi, yakni timbulnya tekanan dalam diri seseorang yang memiliki harapan yang tinggi tetapi memiliki daya saing yang rendah. Perasaan yang tertekan, harapan dan kenyataan yang tidak sejalan, dapat menimbulkan konflik.

Bila dilihat dari dampak yang terjadi untuk masyarakat Indonesia, tentu saja Indonesia harus siap menghadapi berbagai kemungkinan. Masyarakat Indonesia harus memperkuat diri dengan pendidikan agar mereka dapat bersaing dengan masyarakat negara ASEAN lainnya. Dalam menghadapi MEA dengan segala persaingannya dibutuhkan modal untuk memenangkannya. Salah satu modal yang menjadi syarat utama dalam MEA adalah kualitas pendidikan dan keahlian serta keterampilan-keterampilan yang berkualitas. Peran pendidikan perdamaian sangat berperan penting sebagai transformer untuk mengadakan transformasi ideologi terutama menghadapi MEA ini.

\section{Peran Pendidikan Perdamaian dan Pendidikan Agama Kristen dalam Menghadapi MEA}

\section{Pengertian Pendidikan Perdamaian}

Perdamaian adalah hal yang paling mendesak dan paling kuno atau lama dalam agenda kemanusiaan dalam sepanjang sejarah. Dalam semua masyarakat perdamaian telah dan masih merupakan pencarian manusia yang paling 
utama. Pendidikan perdamaian penting karena kita hidup dalam dunia yang diwarnai konflik disertai kekerasan. Memang fenomena ini bukanlah fenomena baru sebab sejak dulu pun konflik telah terjadi yang diikuti oleh berbagai kekerasan pada semua lapisan hubungan antar manusia: antar pribadi, suku, kelompok, bangsa dan sebagainya. Yang paling menyedihkan adalah konflik disertai kekerasan sering terjadi antar kelompok agama, baik dalam satu agama maupun antar agama yang berbeda. Pendidikan perdamaian menjadi suatu kebutuhan dan keharusan, sebab budaya damai tidak dengan sendirinya bertumbuh-kembang dalam diri individu maupun komunitas, apalagi menjadi karakter yang mendarah daging. Untuk yang terakhir malah membutuhkan pendidikan perdamaian melalui habituasi atau pembiasaan agar menjadi karakter baik individu maupun kultur dari organisasi atau komunitasnya.

Istilah pendidikan berasal dari terjemahan bahasa Inggris, yakni 'education' yang diambil atau berasal dari bahasa Latin "ducere" yang berarti "membimbing" (to lead) dan ditambah awalan "e" yang berarti "keluar". Jadi pengertian dasar dari pendidikan adalah suatu tindakan untuk membimbing keluar. Dari pengertian dasar pendidikan ini penulis berpendapat bahwa pendidikan adalah suatu tindakan untuk membimbing keluar dari kebodohan, kemalasan, kebiadaban, kekerasan, kemiskinan, keterbelakangan, ketidaktahuan atau ketidakmengertian supaya tidak bodoh, tidak malas, tidak berlaku biadab, tidak hidup dalam kekerasan, tidak miskin, tidak terkebelakang, supaya dari tidak tahu menjadi tahu atau dari tidak mengerti menjadi mengerti atau paham akan sesuatu terutama hal-hal yang berguna atau bermanfaat.

Pengertian pendidikan menurut Thomas Groome dalam bukunya Christian Religious Education mengutip pandangan Lawrence Cremin yakni "the deliberate, systematic, and sustained effort to transmit, evoke, or acquire knowledge, attitudes, values, skills or sensibilities, as well as any outcomes of that effort". Kekuatan definisi ini menekankan pada pendidikan sebagai kegiatan yang dilakukan secara sengaja, sistematis dan terus-menerus. Kekuatan yang lain adalah mengarahkan kegiatan pendidikan ke arah manusia yang utuh pada pendidikan, sikapsikap, nilai-nilai, keahlian-keahlian dan kepekaan-kepekaan seseorang. Intinya bahwa pendidikan pendidikan mewajibkan pendekatan holistik terhadap manusia yang memperhatikan seluruh seni kehidupan serta memperhatikan potensi-potensi para naradidik dalam konteks lingkungan mereka. 
Perdamaian berasal dari kata dasar 'damai'. Menurut KBBI, damai berarti tidak ada perang, tidak ada kerusuhan, aman, tenteram, tenang, keadaan tidak bermusuhan dan rukun. Berdamai berarti berbaik kembali, berhenti bermusuhan, berunding untuk mencapai kesepakatan. Mendamaikan berarti mengusahakan agar kedua belah pihak berbaik kembali, merundingkan supaya ada persesuaian. Perdamaian berarti menghentikan permusuhan atau menghentikan perselisihan. Dalam bahasa Inggris, 'peace' paling sedikit mempunyai tiga macam pengertian. Kata ini menunjuk pada: freedom from or cessation of war (bebas dari atau berhenti dari peperangan), freedom from civil disorder (bebas dari ketidakaturan sipil) dan tranquility (ketenangan, kesentosaan).

Andar Ismail dalam bukunya Selamat Sejahtera mendeskripsikan damai itu adalah: lepas dari rasa takut, lepas dari rasa khawatir, lepas dari rasa iri dan benci, lepas dari sikap licik dan menang sendiri, lepas dari sikap gelisah, lepas dari sikap marah, lepas dari sikap curiga dan prasangka, lepas dari sikap dendam dan sakit hati. Dengan demikian memperoleh kedamaian itu adalah memiliki rasa aman (save), hidup berdampingan dengan orang lain dalam harmonisasi (live together in harmony), tidak adanya konflik dan kekerasan (not conflict and violence), hidup dalam cinta (live in love), saling peduli (care and respect), saling memberi dan menerima (take and give) dan saling menolong satu dengan yang lain (help each other). Pendidikan perdamaian mempunyai banyak arti yang berbeda-beda untuk individu-individu yang berbedabeda dan di tempat yang berbeda-beda pula. Karena itu dalam tulisan ini, penulis mengambil salah satu definisi yang dirumuskan oleh UNICEF yang mengatakan sebagai berikut:

"Peace education in UNICEF refers to the process of promoting the knowledge, skills, attitudes and values needed to bring about behavior changes that will enable children, youth and adults to prevent conflict and violence, both overt and structural; to resolve conflict peacefully; and to create the conditions conducive to peace, whether at an intrapersonal, interpersonal, intergroup, national or international level."

Definisi di atas dapat diartikan kurang lebih sebagai berikut: pendidikan perdamaian di UNICEF merujuk kepada proses mempromosikan pengetahuan, keterampilan-keterampilan, sikap-sikap dan nilai-nilai yang dibutuhkan untuk membawa perubahan perilaku yang akan memampukan anak-anak, pemuda-pemuda dan orang-orang dewasa untuk mencegah konflik dan kekerasan, baik yang langsung maupun yang struktural; untuk mengatasi konflik secara damai; dan untuk 
menciptakan kondisi-kondisi yang kondusif untuk perdamaian, apakah pada tataran intra-pribadi (dalam diri orang tersebut), antar-pribadi, antar-kelompok, dan pada tingkat nasional atau internasional.

Definisi ini mewakili suatu konvergensi berbagai ide yang sudah dikembangkan melalui pengalamanpengalaman praktis dari program-program pendidikan perdamaian UNICEF di berbagai negara-negara sedang berkembang. Definisi ini juga merefleksikan pemikiran dari sejumlah ahli di bidang ini, dan juga banyak pekerjaan pendidikan perdamaian yang sudah dilakukan di negara-negara industri. UNICEF sendiri berpendapat bahwa pendidikan perdamaian mempunyai tempat dalam semua masyarakat-tidak saja dalam masyarakat yang sedang dilanda konflik bersenjata dan dalam keadaan darurat. Karena bagaimanapun butuh waktu lama untuk terjadinya perubahan perilaku yang tetap dalam diri anak-anak dan orang dewasa. Karena itu pendidikan perdamaian yang efektif adalah proses jangka panjang dan bukan jangka pendek yang idealnya melibatkan seluruh komunitas bukan hanya sekolah.

\section{Tujuan Pendidikan Perdamaian}

Tujuan pendidikan perdamaian adalah untuk mencapai hubungan- hubungan manusia. Namun, bila dilihat dari pengertian damai atau perdamaian sangat luas, maka penulis mencoba membuat suatu daftar tentang cakupan pendidikan perdamaian menurut Ian Harris. Ada sepuluh tujuan pendidikan perdamaian yang diusulkan oleh Ian Harris, yaitu:

Pertama, pendidikan perdamaian memberikan kepada pemikiran naradidik suatu visi dinamis tentang perdamaian untuk melawan (counteract) gambarangambaran kekerasan yang mendominasi budaya kita. Menurut Harris, contohcontoh tentang hal ini bisa berasal dari karya seni, kesusasteraan, maupun dari sejarah. Jadi belajar dari sejarah, memberikan contoh-contoh bagaimana perdamaian telah menstimulasi imaginasi manusia sepanjang sejarah dalam masa yang berbeda-beda.

Kedua, pendidikan perdamaian membahas ketakutan umat manusia. Misalnya ketakutan akan kekerasan yang terjadi di rumah tangga, di jalan, kekerasan terorisme, bahkan ketakutan akan kekacauan iklim dan pemanasan global. Karena ketakutan-ketakutan akan berbagai bentuk kekerasan ini, maka pendidikan perdamaian dapat melakukan intervensi untuk menumbuhkan kesadaran tentang betapa pentingnya perdamaian itu.

Ketiga, pendidikan perdamaian juga mempelajari penyebab-penyebab 
utama dari kekerasan dan perang. Artinya naradidik perlu mempelajari "pengetahuan negatif" tentang daya penghancur dari perang dan penderitaan yang diakibatkan oleh perilaku kekerasan. Dengan mengetahui akibat negatif yang luar biasa dari perang dan kekerasan maka naradidik akan lebih dimotivasi untuk mencintai perdamaian. Meskipun ada saja pandangan yang percaya bahwa budaya damai sudah ada dan tetap ada, hanya saja kadang tersembunyi dalam bauadaya yang lebih besar yang mendorong nilai-nilai yang menyumbang kepada kekerasan dan perang. Dalam konteks budaya-budaya ini, keterampilan mendengarkan dan mempromosikan nilai kepedulian kepada orang lain dianggap yang tertinggi yang menyumbang kepada pembentukan suatu komunitas.

Keempat, pendidikan perdamaian juga bertujuan untuk mempromosikan penghargaan terhadap budaya yang berbeda-beda. Oleh karena perang terjadi akibat konflik antara pengelompokan individu yang berbeda-beda, maka tujuan menghargai perbedaan sangatlah penting untuk terjadinya situasi damai. Naradidik belajar menghargai keragaman dari komunitas manusia. Pemahaman interkultural memberi suatu aspek yang penting dari setiap usaha pendidikan perdamaian. Dalam rangka itu naradidik perlu belajar mengenai kesalingterhubungan manusia dalam planet ini. Survival (tetap hidupnya) dari manusia sangat tergantung kepada kerjasama.

Kelima, pendidikan perdamaian juga perlu memberikan orientasi masa depan kepada para naradidik, dan berjuang untuk menciptakan kembali masyarakat sebagaimana seharusnya. Karena dalam dunia yang penuh dengan kekerasan, naradidik biasanya sudah dilanda oleh keputusasaan. Karena itu, melalui pendidikan perdamaian naradidik perlu diberi gambaran masa depan yang menjadi dasar untuk berpengharapan. Baik pendidik dan naradidik dalam pendidikan perdamaian perlu membayangkan masa depan yang diinginkan dan mendiskusikan bagaimana cara untuk mencapai perdamaian. Jadi perlu ada kursus masa depan mengenai kemungkinankemungkinan lain bagi kehidupan di dalam bumi kita.

Keenam, pendidikan perdamaian tidak hanya menekankan pengetahuan walaupun itu sangat penting, melainkan juga memberi perhatian kepada keterampilan-keterampilan. Kita tidak mungkin menghadirkan perdamaian di dalam dunia kalau kita sendiri tak dapat menghadirkannya dalam kehidupan pribadi kita. Jadi pendidikan perdamaian memusatkan perhatian kepada strategistrategi untuk perubahan individu dan 
masyarakat. Penciptaan damai adalah suatu proses yang harus diajarkan agar manusia dapat mengubah perilaku kekerasannya. Mereka yang ingin mencapai perdamaian memahami bahwa perdamaian adalah suatu proses yang mengubah (transform) kehidupan mereka sendiri ketika mereka mulai mempersonafikasikan visi mereka mengenai masa depan.

Ketujuh, pendidikan perdamaian mencakup pendidikan untuk keadilan. Naradidik perlu belajar mengenai masalahmasalah hak azasi manusia dan keadilan. Mereka perlu memahami bahwa ketiadaan perang tidak dengan sendirinya membawa perdamaian dan harmoni. Jadi, studi tentang perdamaian tidak hanya fokus pada isu-isu keamanan, melainkan menyertakan juga studi tentang keadilan sosial, hak-hak azasi manusia, pembangunan, feminisme, rasisme, nirkekerasan, dan strategi untuk perubahan sosial. Namun untuk memfasilitasi pendidikan perdamaian untuk keadilan, pertama-tama kita harus percaya bahwa keadilan dan perdamaian adalah mungkin. Kita harus percaya bahwa setiap orang dapat berbuat sesuatu untuk menghadirkan keadilan dan perdamaian. Pendidik harus benar-benar menyadari tentang akibat penindasan, dan menggunakan pengetahuan ini untuk memberdayakan orang lain untuk melawan institusi- institusi yang dominan dan memaksa (coercive).

Kedelapan, pendidikan perdamaian bertujuan untuk menolong setiap naradidik menghargai segala bentuk kehidupan dengan mengatasi berbagai kecenderungan manusia untuk melakukan kekerasan. Dalam kaitan itu, naradidik perlu mengembangkan gambaran diri yang positif, rasa tanggungjawab terhadap diri sendiri dan orang lain, dan kapasitas untuk mempercayai pihak lain, dan peduli kepada kesejahteraan dari dunia natural (lingkungan hidup). Pendidikan perdamaian menyumbang kepada perkembangan sosial semua anak, misalnya perasaan berharga dan bermartabat dan lain-lain yang sangat penting untuk mencapai perdamaian. Pendidikan perdamaian mengajarkan kepedulian dan empati, bukan hanya pemahaman rasional terhadap berbagai masalah yang dihadapi orang-orang lain. Kepedulian pun tidak hanya terhadap orang-orang lain, melainkan juga terhadap planet kita dengan menghargai keseimbangan ekologis yang mendukung kehidupan.

Kesembilan, tujuan akhir dari pendidikan perdamaian adalah untuk mengelola dan mengubah (transform) konflik-konflik secara nir-kekerasan, dan agar para naradidik diberdayakan menjadi agen-agen perubahan sosial, demi suatu 
dunia yang lebih baik. Hal ini penting, karena dunia kita telah dilanda oleh perilaku kekerasan dalam berbagai bentuknya: di jalan raya, dalam keluarga, dalam konflik-konflik antar kelompok dan bangsa, bahkan dalam situasi kemiskinan yang menyebabkan jutaan orang harus berjuang untuk tetap hidup. Perlu diakui bahwa tugas ini tidaklah mudah.

Dengan mengutip berbagai tujuan pendidikan perdamaian di atas, maka jelaslah betapa luas dan menyeluruhnya pendidikan perdamaian itu dan semua itu merefleksikan definisi pendidikan perdamaian yang dirumuskan oleh UNICEF tadi. Pada saat yang sama, kita semakin menyadari betapa pentingnya pendidikan perdamaian itu untuk keberlangsungan dari peradaban manusia, agar tidak terjerumus ke dalam situasi yang menyebabkan manusia saling menghancurkan, terutama dalam menghadapi MEA ini.

\section{Pendidikan Perdamaian dan Pendidikan Agama Kristen}

Tugas pendidikan perdamaian adalah tugas semua pihak: pemerintah, masyarakat, komunitas-komunitas agama dan gereja. Dengan demikian, tugas pendidikan perdamaian adalah juga bagian integral dari tugas PAK dan oleh karena itu perdamaian menjadi isu tetap dalam
PAK kapanpun dan di manapun. Salah satu nilai yang penting dalam Kekristenan adalah perdamaian termasuk di dalamnya perdamaian atau rekonsiliasi dengan Tuhan sendiri. Tujuan kedatangan Kristus ke dalam dunia ini adalah untuk mendamaikan dunia ini dengan khalikNya, yakni Allah. Tuhan mempercayakan tugas pendamaian itu kepada gereja-Nya dan setiap orang percaya, sebagaimana dikatakan: "Sebab Allah mendamaikan dunia dengan diri-Nya oleh Kristus dengan tidak memperhitungkan pelanggaran mereka. Ia telah mempercayakan berita pendamaian itu kepada kami" (2 Kor 5:19).

Pendidikan perdamaian harus ada dalam kurikulum-kurikulum PAK dan harus menjadi bagian hidup setiap orang. Budaya damai adalah cerminan karakter setiap orang. Pertanyaannya adalah apakah kurikulum pendidikan gereja atau PAK baik itu untuk jemaat, konteks keluarga, dan sekolah sudah cukup memberi tempat kepada pendidikan perdamaian. Kalau UNICEF telah menjadikan pendidikan perdamaian sebagai gerakan global padahal gereja belum memberi respons yang memadai terhadapnya, maka ada sesuatu yang salah dalam pemahaman gereja mengenai tugasnya dalam dunia ini.

Dewan Gereja-Gereja Dunia memang pernah mempunyai tema besar yang dikenal dengan Justice, Peace, and 
Integrity of Creation (Keadilan, Perdamaian dan Keutuhan Ciptaan), dan sudah ada berbagai upaya untuk mensosialisasikan tema ini di kalangan gereja-gereja anggota. Sayangnya usaha ini belum menjadi prioritas di tahap gereja lokal. Seharusnya ini merupakan gerakan yang berkesinambungan karena dunia kita sedang dilanda oleh berbagai konflik dan kekerasan.

Keunikan peran gereja (dan juga agama-agama) dalam pendidikan perdamaian adalah masalah perdamaian diberi dasar iman atau spiritualitas, misalnya perdamaian itu juga adalah tugas esensial gereja dan agama-agama. Perdamaian bukan saja tugas gereja dan agama-agama, melainkan perdamaian juga mencakup perdamaian dengan Tuhan khalik alam semesta termasuk manusia. Tugas perdamaian bahkan budaya damai diberi dasar religius dan imaniah, karena dimulai dari hubungan manusia dengan Tuhan lalu diwujudkan dalam hubunganhubungan manusia: dengan diri sendiri, dengan sesama dan dengan alam ciptaan Tuhan.

Keunikan yang lain dari peran gereja adalah ajaran bahwa perdamaian dimungkinkan kalau ada kesediaan meminta maaf dan memberi pengampunan manakala konkflik sudah terjadi, sebagaimana juga dalam hal hubungan kita dengan Tuhan. Kita diperdamaikan dengan
Tuhan karena Tuhan rela mengampuni manusia, karena itu kita dituntut untuk berdamai dengan sesama. Kita terus memohon pengampunan namun kita sulit memberi pengampunan kepada sesama, dan karena itu kita menggunakan standar ganda. Banyak konflik manusia dalam organisasi lebih suka diselesaikan dengan jalan litigasi (hukum) dan berpikir itulah cara terbaik walaupun disadari sepenuhnya bahwa hasilnya akan berakhir dengan kemenangan dan kekalahan.

Amanat Allah bahwa semua orang harus diam dengan rukun dan damai. Memahami dan menjalankan kehidupan bersama dalam keadaan yang baik dan indah. Dalam Mazmur 133:1-3 berbunyi "Sungguh, alangkah baiknya dan indahnya, apabila saudara-saudara diam bersama dengan rukun! Seperti minyak yang baik di atas kepada meleleh ke janggut, yang melelah ke janggut Harun dan ke leher jubahnya. Seperti embun gunung Hermon yang turun ke atas gunung-gunung Sion. Sebab ke sanalah TUHAN memerintahkan berkat, kehidupan untuk selama-lamanya."

\section{Bagaimana Menghadapi MEA dengan Pendidikan Perdamaian}

Dalam menghadapi MEA ini dengan segala bentuk tantangan dan dampaknya, diperlukan strategi untuk 
menghadirkan pendidikan perdamaian. Karena pendidikan perdamaian bukan hanya konten saja, tetapi sesuatu yang harus dilakukan, dikerjakan dan diciptakan. Pendidikan perdamaian menjadi fondamen atau dasar yang baik atau pijakan yang baik serta kokoh, karena tantangan sudah di depan mata. Menghadapi tantangan dalam MEA bukanlah sesuatu yang harus dihindari tetapi haruslah dihadapi. Hal-hal yang perlu diperhatikan, adalah sebagai berikut:

- Pendidikan perdamaian mengajarkan manusia untuk berdamai dengan diri sendiri terlebih dahulu, dan setiap orang harus memiliki rasa damai dalam menghadapi persaingan.

- Memberikan pandangan untuk dapat bekerjasama dengan negara lain dalam mencapai tujuan dari MEA.

- Pendidikan perdamaian mengajarkan hidup dengan damai dan saling bekerjasama dengan baik dan bersaing dalam kualitas yang sehat di dalam MEA.

Dalam menghadapi MEA, memperoleh kedamaian adalah memiliki rasa aman, hidup dalam harmonisasi dengan orang lain, saling mengerti, menjalin komunikasi yang baik, tidak adanya konflik dan kekerasan, saling peduli, saling menolong, dan seterusnya.

Tujuan pendidikan perdamaian yang sudah dijelaskan sebelumnya, haruslah menjadi agenda penting untuk dilakukan oleh semua pihak. Pendidikan Agama Kristen di sekolah-sekolah harus mengagendakan dan menjadi bagian kurikulum yang penting untuk diajarkan. Pokok-pokok pengajaran gereja juga harus menyentuh pengajarannya mengenai perdamaian ke semua anggota jemaatnya. Sebab tugas pendidikan perdamaian adalah tugas yang dipercayakan Kristus untuk dilakukan oleh gereja. Kitalah duta-duta perdamaian di mana bumi kita pijak artinya perdamaian haruslah dimulai dari diri kita, lingkungan, keluarga, sekolah, gereja, masyarakat, bangsa dan negara.

Tantangan-tantangan yang dihadapi bukan menjadi masalah yang berat dan menjadikan seseorang atau individu, kelompok, bangsa/negara mudah terpancing untuk melakukan tindakantindakan kekerasan. Tujuan pendidikan perdamaian haruslah menjadi acuan dalam kehidupan bersama di era MEA ini. Pendidikan perdamaian yang bertujuan untuk menjunjung nilai-nilai saling memahami dan toleransi terhadap perbedaan, meminimalkan konflik dan kekerasan, sudah menjadi suatu kebutuhan yang harus dilakukan. Dibutuhkan penyelesaian yang serius yang harus dilakukan oleh semua pihak.

Dalam setiap perjumpaan tentu saja ada begitu banyak perbedaan yang ditemui, baik perbedaan latar belakang 
hidup, gaya, ras, budaya, agama, bangsa, tentu saja akan ditemui dalam era MEA ini. Kemajemukan atau kepelbagaian yang ditemui terutama perbedaan-perbedaan pendapat dalam bertransaksi, menjalin hubungan, berkomunikasi, dan seterusnya, haruslah dapat dilakukan dengan cara-cara berhubungan yang aman dan damai. Karena nilai-nilai perdamaian adalah nilainilai yang harus dijunjung tinggi dalam rasa kemanusiaan. Bilamana hal itu tidak dilakukan, maka tentu saja masalahmasalah ataupun konflik-konflik bahkan kekerasan yang selalu ditemui. Hal ini tidak sejalan dengan pendidikan perdamaian yang bertujuan untuk menjadikan dunia yang aman, bebas dari konflik, kekerasan ataupun tindakantindakan yang berakibat pada kekacauan dan perang. MEA akan membawa bangsa dan negaranya dengan jati dirinya. Indonesia sebagai bangsa yang bermoral dan beradab, tentu saja akan menjunjung tinggi nilai-nilai kemanusiaan dan perdamaian di atas kepentingankepentingan individu-individu yang merugikan pihak lain dengan cara tidak bertanggung jawab. Perdamaian menjadi karakter bangsa yang harus dilakukan lewat pembiasaan-pembiasaan dan sebagai cara hidup atau gaya hidup setiap orang. Dengan demikian Indonesia tidak akan kehilangan jati dirinya dan tidak ragu-ragu dalam menghadapi era MEA yang serba kompetitif.

\section{Penutup}

Masyarakat Ekonomi Asean adalah sebuah kenyataan dalam kehidupan bersama di antara negara-negara Asean dengan segala bentuk program terutama di bidang Ekonomi. Peluang yang menguntungkan tentu saja segera diambil dan disikapi baik oleh individu, kelompok atau bangsa untuk mendatangkan keuntungan dan kemanfaatan bagi masingmasing pihak. Namun, di samping peluang ada juga tantangan-tantangan yang harus dihadapi terutama untuk memperlengkapi diri dalam meningkatkan kualitas atau mutu yang harus terjamin. Kualitas pendidikan yang baik adalah kunci sukses dalam era Masyarakat Ekonomi Asean. Sebab, jika kualitas pendidikan rendah dan tidak terjamin akan berpengaruh pada terseleksinya kesempatan untuk mendapatkan pekerjaan. Di samping itu, karakter dan perilaku yang baik akan turut mempengaruhi sebagai bentuk kepercayaan orang lain. Di Era MEA semuanya serba terseleksi dan kompetitif, sehingga semua pihak haruslah siap dan matang.

Hal-hal lain yang turut berpengaruh dalam era MEA, yakni konflik bisa saja muncul karena berbagai alasan. Orang 
yang merasa tidak diperhitungkan atau tidak mendapatkan kesempatan kerja karena tidak diterima, individu, kelompok atau perusahaan yang kalah atau gagal berbisnis, semuanya ini dapat saja mengakibatkan konflik atau masalahmasalah. Konflik-konflik ini dapat berakibat pada kekerasan, yakni dari skala kecil sampai skala yang akut. Semuanya ini perlu untuk mendapatkan penanganan lebih lanjut agar konflik-konflik tersebut dapat tertangani atau dapat teratasi. Pendidikan perdamaian adalah fondamen yang baik menghadapi tantangantantangan terutama mengatasi berbagai konflik. Pendidikan perdamaian mengajarkan manusia untuk berdamai dengan diri sendiri terlebih dahulu, setiap orang harus memiliki rasa damai dalam menghadapi persaingan. Memberikan pandangan untuk bekerjasama dengan negara lain dalam mencapai tujuan MEA. Pendidikan perdamaian mengajarkan hidup dengan damai dan saling bekerja sama dengan baik dan bersaing dalam kualitas yang sehat di dalam MEA.

Pendidikan perdamaian haruslah dikerjakan oleh semua orang tanpa terkecuali, menjadi ajaran yang penting dalam semua aspek kehidupan dan menjadi kebiasaan sehari-hari di mana saja seseorang itu berada, yakni di rumah, gereja, sekolah, tempat kerja, di jalan dan di mana saja. Dengan menerapkan pendidikan perdamaian sebagai bentuk kebiasaan sehari-hari, maka segala bentuk konflik dapat dicegah dan diatasi. Inilah tujuan pendidikan perdamaian kaitannya dengan Pendidikan Agama Kristen dalam menghadapi Masyarakat Eknonomi Asean. 


\section{Daftar Pustaka}

Danish, H.B. Education for Peace Reader. Victoria: EFP Press, 2011.

Departemen Pendidikan dan Kebudayaan. Kamus Besar Bahasa Indonesia edisi ketiga. Jakarta: Balai Pustaka, 2000.

Ismail, Andar. Selamat Sejahtera. Jakarta: BPK Gunung Mulia, 2002.

Kementerian Perdagangan Republik Indonesia. Informasi Umum Masyarakat Ekonomi ASEAN: ASEAN Community in a Global Community of Nations. Jakarta: Direktorat Jenderal Kerjasama Perdagangan Internasional. 2011.

Masyarakat Eekonomi Asean-Misi Perdamaian. http://www.mirajnews.com/id/masyarakatekonomi-asean-misi-perdamaian (diunduh tanggal 18 Mei 2016).

Nuhamara, Daniel, Pembimbing PAK. Bandung: Jurnal Info Media, 2010.

Santoso, W. et.al. Outlook Ekonomi Indonesia 2008-2012: Integrasi Ekonomi ASEAN dan Prospek Perekonomian Nasional. Jakarta: Biro Riset Ekonomi Direktorat dan Kebijakan Moneter, 2008.

Fountain, Susan. Peace Education in UNICEF. New York: United Nations Children's Fund, 1999.

Groome, Thomas H. Christian Religious Education. San Fransisco: Harper \& Row Publisher, 1980.

www.bbc.com (diunduh tanggal 18 Mei 2016).

Yewangoe, Andreas A. Pendamaian. Jakarta: BPK Gunung Mulia, 1983. 